\title{
Tenure for Professional Librarians on Appointment at Colleges and Universities
}

\begin{abstract}
This paper is another in the series of statements drafted by a member of the Committee on Academic Status of the University Libraries Section of the Association of College and Research Libraries, and approved by the committee as preliminary reports to elicit comment. Readers' reactions are invited and may be sent to the chairman of the committee. Following possible revision and final approval by the committee, it is expected to submit all statements to ACRL for endorsement and publication in monographic form.

Current members of the committee are R. B. Downs, William H. Jesse, Robert H. Muller, David C. Weber, and Lewis C. Branscomb, chairman.
\end{abstract}

$P$ Rofessional librarians are involved in intellectual and other tasks that can be performed only in an atmosphere of freedom. Examples of such tasks are: (1) the selection of publications, including determination of what to discard from an existing collection and what to accept or reject from donors; (2) the determination of restrictions of circulation or access with regard to controversial library materials; ( 3 ) the determination of the degree of prominence in the shelving of selected library materials; (4) determination of exhibit programs involving controversial subjects; (5) the employment of staff members alleged to have or who express nonconformist opinions, habits, manners, or appearance;

Dr. Branscomb is Director of Libraries and Professor of Library Administration, The Ohio State University.
(6) the issuing of bibliographies that might include controversial publications; (7) the planning or design of well thought out but possibly unorthodox library facilities; (8) the defense of library policies in the face of unjust accusations; (9) publishing of articles or books and delivery of speeches in defense of the principles of free speech and the unhampered pursuit of truth, etc.; (10) the use of defensible, but unorthodox classifications, subject designations in catalogs, or labels for books; (11) the adoption of promising but untried methods of operation or management; and (12) the advising of students as to what to read or study.

Freedom in the performance of such tasks means the absence of fear of dismissal or reprisal in the event that the performance happens to arouse the displeasure or disapproval of governing au- 
thorities, pressure groups, or other selfappointed guardians over mass communications.

Permanent or continuous tenure for professional librarians at colleges and universities is essential for the free and untrammelled performance of such tasks just as freedom is essential for the faculty involved in classroom teaching or research. It implies freedom to carry on the work of the library, conduct research, and engage in extramural activities. It also implies a sufficient degree of job security to make the profession attractive to men and women of ability. Without these indispensable conditions, the professional staff of a library cannot fulfill its obligations to its institution and to society. The privileges of tenure are obvious, but there are obligations which must accompany tenure such as speaking and writing with accuracy, the exercise of appropriate restraint, respect for the opinions of others, and an indication that the librarian is not an institutional spokesman when speaking as a citizen.

The terms and conditions of every appointment should be stated in writing and be in the hands of the institution and of the librarian in advance of the execution of the appointment.

\section{The Achievement of Tenure}

An institution in which librarians have been accorded faculty rank and title ranging from instructor through full professor on an equal basis with the classroom faculty will appropriately include the professional librarians under the same provisions for achieving tenure as other members of the faculty. This usually involves a period of probation ranging from three years to seven years at the level of instructor or assistant professor, and somewhat shorter periods for the top ranks, with periodic evaluations of the performance of a given faculty member. Professional librarians achieve tenure as to professorial rank, but not as to administrative position or individual assignment.

During the period of probation the decision may be made in any year that the library staff member's contract will not be renewed. Notice of nonreappointment, or of intention not to recommend reappointment to the governing board, should be given in writing in accordance with the following standards.

1. Not later than March 1 of the first academic year of service, if the appointment expires at the end of that year; or, if a one-year appointment terminates during an academic year, at least three months in advance of its termination.

2. Not later than December 15 of the second academic year of service, if the appointment expires at the end of that year; or, if an initial two-year appointment terminates during an academic year, at least six months in advance of its termination.

3. At least twelve months before the expiration of an appointment after two or more years in the institution.

The staff member has an equal responsibility to fulfill his contract and to provide his institution with a written notice of intent to resign on the same time schedule as that followed by the institution. If the decision is made not to grant tenure, the staff member is so notified at least a year before the end of the probationary period; if appropriate, the library may assist him to find another position for which he is better qualified. It is assumed automatically that a person has achieved tenure at the end of the trial period if he has not been officially notified in writing that his contract will not be renewed. During the probationary period librarians have the same academic freedom that all other members of the library staff and of the classroom faculty enjoy.

\section{Termination for Cause}

Upon the achievement of tenure, the librarian leaves the employ of the institution only through voluntary resignation, retirement, death, or dismissal for cause. Dismissal for cause may be based upon incompetence, moral turpitude, or (Continued on page 341 ) 
These are but a few of the activities of various committees chosen from the annual reports submitted to the president and to the executive secretary. Other committees have been equally active and their work constitutes a major contribution. One always runs the risk in selecting a few items for comment of overlooking the more important.

Participation in the meetings of the ACRL Board of Directors as vice-president in 1963-64 made obvious the difficulties imposed by the size of the board. In an effort to achieve a more effective relationship, the Planning and Action Committee undertook certain changes which would reduce the number of members. First, the Teacher Education Libraries Section, by vote of its members is being discontinued this year. Second, the proposed amendment to Article $\mathrm{V}$ of the constitution would eliminate the past chairmen of sections from membership on the board.

Another proposed amendment provides for chapters to be organized. This would encourage the establishment of new chapters, and legalize the existence of some still active from earlier efforts in this field. Such action was recommended by the ACRL Committee on Organization in its Report of June 1960, but never implemented.

One other action this year has been accomplished through the Publications Committee, that is, the determination of terms of office of each of the editors of ACRL publications.

The legislative Advisory Committee to the President has had an important part in support of the proposed Higher Education Act of 1965. As president of ACRL, I appeared before the House Subcommittee on Education in support of this legislation in March 1965. Along with me were Robert Downs, John Scott, and Jean Lowrie. At the hearings before the Senate Subcommittee on Education, Edmon Low and Morris Gelfand were our representatives.

Altogether the year has been one of considerable activity, and one which shows progress and promise for even greater participation on the part of ACRL in the American Library Association and its program.Archie L. McNeal.

\section{PROFESSIONAL LIBRARIANS}

(Continued from page 298)

grave misconduct inimical to the best interest of the institution. In all cases where the facts are in dispute, charges in writing are presented to the library staff member, and the matter is considered by a committee of his peers. Anyone against whom charges have been made is given due notice, is presented with the written charges and is allowed a reasonable opportunity to reply. The rights of representation, submission of evidence, and the introduction of witnesses shall be granted to both the institution and the person charged, and a full record of the hearings shall be kept. The committee shall make findings of fact, and such recommendations as it may deem appropriate shall be submitted to the president of the institution. A professional librarian on continuous appointment who is dismissed for reasons not involving moral turpitude shall receive his salary for at least a year from the date of notification of dismissal, whether or not he is continued in his duties at the institution. Termination of a continuous appointment because of financial exigency should be demonstrably bona fide. The administrative officer's right to dismiss a staff member for a particular cause may be lost if he fails to inform his staff member of the unsatisfactory nature of his services and does not take the prescribed action within a reasonable time.

While the above statements are recommended for adoption by library administrations where professional librarians are accorded faculty rank and title, in institutions where librarians are under another system, the library administration is advised to establish a tenure procedure similar in nature and principle to that described above. The foregoing statements represent an effort to formalize the best current practice, rather than a marked departure from present practice. 